SHS Web of Conferences 24, 02008 (2016)

DOI: $10.1051 /$ shsconf/20162402008

(c) Owned by the authors, published by EDP Sciences, 2016

\title{
Incentive paradox analysis in the process of applied talents training of private colleges
}

\author{
Lingli $\mathrm{Chu}^{1} \&$ Jiang Guo ${ }^{2}$ \\ ${ }^{1} X i$ 'an Fanyi University, Xi'an, Shaanxi, China \\ ${ }^{2} X i$ 'an University of Finance and Economics, Xi'an, Shaanxi, China
}

\begin{abstract}
For solving incentive paradox between the traditional teaching evaluation methods oriented by applied talents training and the goal of applied talents training, this paper builds the closed-loop constraint system of target incentive of the applied talents training and puts forward target incentive measures from three levels teaching affairs department, teachers and students.
\end{abstract}

Keywords: incentive paradox; target incentive; applied talents training

\section{INTRODUCTION}

In recent years, with the transformation of the higher education from meritocracy to mass-oriented education, the applied talents training has become the development orientation for the majority of private colleges ${ }^{[1]}$. Such target orientation does not meet the demand of current market for professional talents ${ }^{[2]}$. Among them, not effectively implementing the goal of the applied talents training is one of the most important internal factors (Peng Lei, 2011; Chu Lingli, 2013) ${ }^{[3,4]}$. The inconsistency between the target and the result is known as "incentive paradox". Based on the game theory, this paper attempts to research the "incentive paradox" of the applied talents training of private colleges under the traditional teaching mode, explore an effective way to solve contradictions between supply and demand in the talents training of private colleges, and promote further professional deepening reform of the talents training of private colleges from three levels: teachers, students and management level.

\section{INCENTIVE PARADOX BETWEEN TEACHING SUBJECTS}

The effective realization of the talents training goal depends on the rational allocation and implementation of the teaching content and teaching process. There are two important participants in this process: teachers and students, and there is also a manager: dean's office of the private college. In the teaching process, teachers are givers about knowledge and ability, and students are receivers. Whether the teaching objectives can be achieved depends on the teachers and students. Therefore, the establishment of incentive mechanism about teachers and students directly affects the realization of talents training goal. As a dean's office of the private college, the manager is also a supervisor of learning behavior and developer of teaching incentive system, and also represents the stakeholders of the private colleges. Therefore, in the process of talents training, there is a mutual restraint between behavioral selection of teachers and students, and also a complex game relationship restricted by colleges.

Assuming that the teachers, students, and dean's office of the private colleges are rational people, the teachers and students have their sluggishness and view the current benefit maximization as a sole standard of behavioral selection. The management goal of the dean's office is to achieve the talents' training goal; the teacher's teaching goal is the workload minimization under the condition of constant income; the student's learning goal is to pass the exam. In the teaching process, there are two incentive game matrixes:

1. Selection benefit matrix in the teaching process

In the teaching process, the teachers have two teaching methods to select: knowledge teaching (cramming method of teaching) and applied teaching (interactive teaching); the students also have corresponding learning methods to select: passive learning 
Students

Teachers Knowledge teaching Applied teaching

Passive learning Participatory learning

\begin{tabular}{|ll|ll|}
\hline 0 & $\mathrm{~S}$ & $\mathrm{~T}$ & 0 \\
\hline$-\mathrm{T}$ & $\mathrm{S}$ & 0 & 0 \\
\hline
\end{tabular}

Figure 1. Selection matrix of teachers and students in the teaching process

\begin{tabular}{|c|c|c|c|}
\hline \multicolumn{4}{|c|}{ Students } \\
\hline \multirow{3}{*}{ Teachers } & \multirow{3}{*}{$\begin{array}{l}\text { Result evaluation } \\
\text { Process evaluation }\end{array}$} & Usual effort & Final cramming \\
\hline & & $\begin{array}{|ll|}\mathrm{K} & -\mathrm{P} \\
\end{array}$ & 0 \\
\hline & & 0 & $-\mathrm{K} \quad-\mathrm{P}$ \\
\hline
\end{tabular}

Figure 2. Incentive benefit matrix of teachers and students in teaching evaluation

and participatory learning. The benefit matrix of behavioral selection of game parties is shown in Figure 1.

In this matrix, if the teachers select teaching method to give lessons and the students select passive learning, the teachers do their own job with the benefit of 0 , but the students spend less energy to participate, which meets the sluggish psychology with the benefit of S; if the students select participatory learning, the teachers improve teaching effectiveness with the benefit of $\mathrm{T}$, but the students do their own work as learning subjects with the benefit of 0 . On the contrary, if the teachers select applied teaching method, and the students select passive learning, the teachers fail to achieve the expected teaching effectiveness with the benefit of $-T$, but the students meet the sluggish psychology with the benefit of S; however, if the students select participatory learning, the teachers can reach the objective teaching effectiveness, and the students do their own learning work with both benefit of 0 .

Viewing from the game matrix, regardless of the teachers selecting knowledge teaching or the applied teaching, the best choice for students is passive teaching. However, if most of the students select passive teaching due to the sluggish psychology, the best choice for teachers is knowledge teaching. Due to the selection of knowledge teaching method, the effort of teachers is equal to benefit, which is in a balanced state; on the contrary, to select the applied teaching, the effort of teachers is greater than benefit with a negative income. Therefore, in the teaching process, the free game result of the teachers and students is that the teachers select knowledge teaching while the students select passive learning. However, the game result is inconsistent with the applied talents training goal of the private colleges. Therefore, without considering other incentive factors, there is an incentive paradox between the existing teaching process and the training goal towards talents of the private colleges.

2. Incentive benefit matrix in teaching evaluation

Based on the incentive paradox between the game results of teachers and students in the teaching process of private colleges and the training goal of talents, the authors further examines the impact of teaching eval- uation method on this result. Assuming that the teachers select the knowledge teaching method, the corresponding choice is the result evaluation method, which is used to assess the teaching effectiveness; on the contrary, if the teachers select the applied teaching method, the corresponding choice is the process evaluation method. In the teaching evaluation incentive for the professional curriculum, the teachers can select two evaluation methods: result evaluation and process evaluation; assuming that the students select passive learning, an effective weapon to pass the exam is final cramming, but select participatory learning method, an effective weapon to pass the exam is usual effort. Therefore, students also have two ways to deal with exams: usual effort and final cramming. The game matrix of behavioral selection of game parties is shown in Figure 2.

In this matrix, if the teachers select the result evaluation to examine the teaching effectiveness, and the students select final cramming to pass the exam, the teachers and students can reach the target with the benefit of 0 ; if the teachers select the result evaluation and the students select usual effort, the teachers will improve the teaching effectiveness with the benefit of $\mathrm{K}$. Due to the time limit of the knowledge memory, the students may not pass the result evaluation in the final exam with the benefit of -P. On the contrary, if the teachers select the process evaluation and the students select participatory learning with usual effort, the teachers and students can reach the target with the benefit of 0 ; if the teachers select the process evaluation and the students select final cramming, the teachers fail to reach the teaching target and the students fail to pass the exam, so the benefit of the teachers and students are negative.

This matrix shows that, if the teachers select the result evaluation method to examine the teaching effectiveness, the best choice for the students to pass the exam is the method of final cramming; if the teachers select the process evaluation method to examine the teaching effectiveness, the best choice for the students to pass the exam is participatory learning with usual effort. On the contrary, if the students select participatory learning with usual effort, the best choice for 
SSHE 2015

Teachers and students

Dean's Target incentive

office Non-target incentive

Target teaching and learning
\begin{tabular}{|lll|lll|}
\hline 0 & 0 & 0 & $-\mathrm{A}$ & $-\mathrm{B}$ & $-\mathrm{C}$ \\
\hline $\mathrm{A}$ & $-\mathrm{B}$ & 0 & $-\mathrm{A}$ & 0 & 0 \\
\hline
\end{tabular}

Figure 3. Incentive benefit matrix of schools, teachers and students

the teachers is the result evaluation; if the students select the final cramming method, the teachers will also select the result evaluation due to the goal of benefit maximization. Therefore, the result of this matrix game shows that, considering from the benefit maximization, the teachers will select the knowledge teaching method and the method of result evaluation to examine the teaching effectiveness under the presence of the sluggish psychology and assumptions of free choice of teaching evaluation methods,. Correspondingly, the students naturally select the passive learning with final cramming method. There is also an incentive paradox between the game results of teachers and students in the evaluation and the applied talents training goal of the private colleges.

\section{ESTABLISHMENT OF TARGET INCENTIVE SYSTEM AND BREAKTHROUGH OF INCENTIVE PARADOX}

Viewing from the above two game matrix analysis, in the process of talents training of the private colleges, whether the applied talents training goal can be achieved mainly depends on how to promote the transformation of teaching methods, learning methods and evaluation methods, and breaking the incentive paradox between teachers and students in the teaching process and incentive paradox of the evaluation methods. To promote the transformation of teaching methods, learning methods and evaluation methods, it is inseparable from the effective management and system incentive of the teaching management departments of the private colleges. In this process, there is also a game relationship between the behavior of teachers and students and the behavioral selection of the managers. Assuming that the teaching affairs department has two choices - establish a sound target incentive mechanism or not, the teachers have two corresponding choices-target teaching (applied teaching) with the target incentive and freely selected non-target teaching (knowledge teaching) without the target incentive, and the students also have two choices - the effective learning with target (participatory learning with usual effort) and the ineffective learning without target (passive learning with final cramming). The selection game matrix is shown in Figure 3.

In this matrix, the benefit of the dean's office is represented by $\mathrm{A}$, the benefit of teachers is represented by $\mathrm{B}$, and the benefit of students is represented by $\mathrm{C}$. If the dean's office selects the target incentive measures, and the teachers and students select the target teaching and learning, they can just achieve the target and benefit with the benefit of 0 ; on the contrary, if the teachers and students still select non-target teaching and learning, they will be punished, and the benefit of teachers is $-\mathrm{B}$; if the school fails to achieve the applied talents training goal, the benefit of the school is $-\mathrm{A}$, and the benefit of the students is - $\mathrm{C}$. If the dean's office is free of target incentive and the teachers select target teaching, the teachers shall overcome sluggishness and spend energy devoting to teaching with the benefit of $-\mathrm{B}$; if the school achieves the applied teaching target, the benefit is A; on the contrary, if the teachers select non-target teaching, its investment is equal to the benefit with the benefit of 0 . However, if the school fails to achieve the applied talents training goal, the benefit is -A.

Therefore, if the dean's office does not establish a sound target incentive system, the teachers will select non-target teaching due to sluggishness, while the students will select non-target learning due to short-term target; on the contrary, if the dean's office takes the initiative to establish a sound target incentive for target management, the teachers will select the applied teaching and process evaluation under the effect of incentive, while the students will select the participatory learning and usual efforts.

As can be seen from the above three game matrixes, whether the applied talents training goal of the colleges can be achieved is mainly to break the game benefit pattern between the teachers and students. However, it depends on whether the teaching affairs department can establish an effective target incentive system.

\section{WAY TO ESTABLISH THE APPLIED TEACHING METHOD AND PROCESS EVALUATION SYSTEM UNDER THE PERSPECTIVE OF TARGET INCENTIVE}

1. Operating mechanism of target incentive measures in the process of applied talents training

Based on the game relationship in the talents training process, the establishment of effective target incentive mechanism by the school is an effective way to realize the goal of applied talents training in reality. However, there is a closed-loop constraint system of target incentive in the process of applied talents training, as shown in Figure 4.

In the closed-loop system, first, due to the competition in the talents demand market, the private colleges will exercise the monitoring function for the executing 


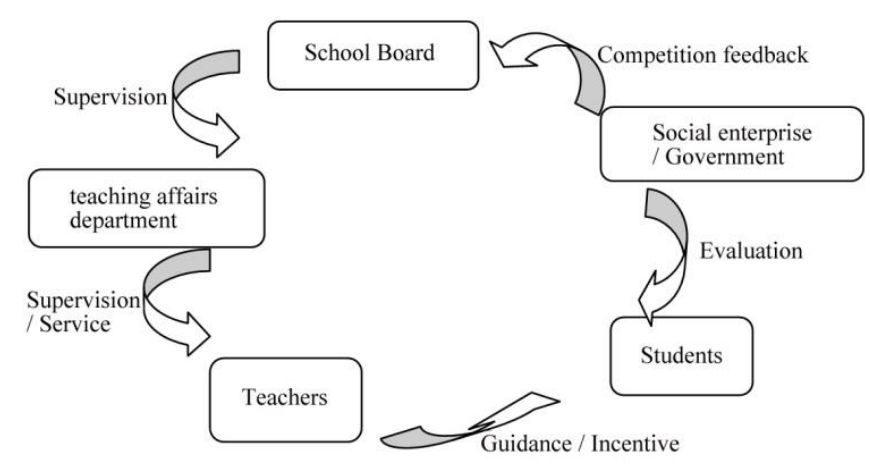

Figure 4. Closed-loop system of target incentive in the applied talents training

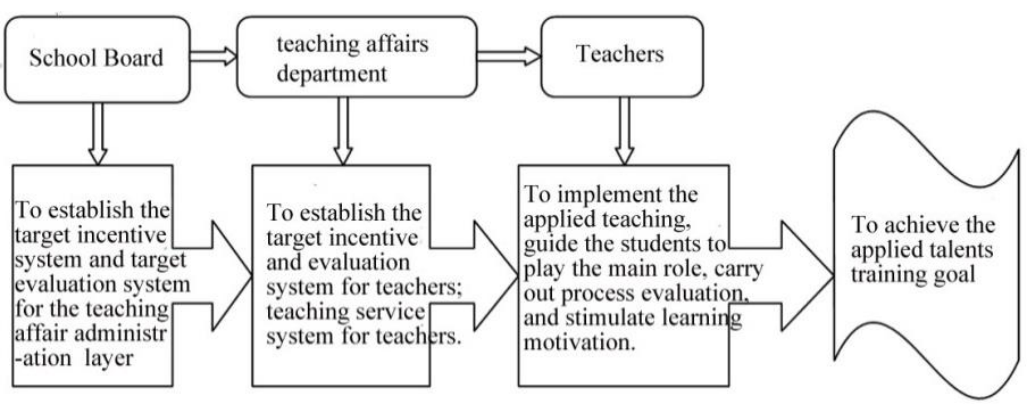

Figure 5. Way to establish the applied teaching and process evaluation system

agency of the teaching affair administration, and promote the teaching affairs department to perform the management work according to the applied talents training goal developed by the school. Under the pressure of the Board, the teaching affairs department can carry out the management and supervision of the target incentive through the establishment of effective target management and incentive mechanism, and pay attention to give play to the teachers' teaching initiative.

Second, under the guidance of the target incentive and restraint system of the teaching affairs department, the teachers give play to the leading role of teaching and the initiative to implement teaching, mobilize the students' intrinsic motivation of participatory learning, improve the class quality, enhance the students' learning initiative, and promote combination with the classroom teaching and social needs.

Finally, under the pressure of process evaluation and participatory learning, it can not only enhance the students' learning efficiency, but also indirectly achieve long-term common goal of applied talents training. In this way, the graduates will be recognized by social enterprises, and the school will also improve the competitiveness in the employment market. Therefore, to achieve favorable operation of the closed-loop system of target incentive, there is a must to define and specify the target incentive relations between the teaching affairs department, teachers and students, and develop perfect target incentive measures and supervision enforcement system.

2. Specific way to establish the applied teaching methods and process evaluation systems

According to the operation mechanism analysis of the closed-loop system of target incentive mechanism, there is a must to establish appropriate target incentive systems for establishing effective applied teaching methods and process methods for the applied talents training. The specific methods are shown in Figure 5.

First, the board of the private college should establish the target incentive system and target evaluation system for the teaching affair administration layer. This system can promote the teaching affairs department to establish the corresponding target incentive and evaluation system for the teaching process. The target incentive system can promote the teachers to turn to the applied teaching, improve the teachers' professional responsibility and specify the applied teaching goal of the teachers.

Meanwhile, the teaching affairs department should establish an effective serve system for the implementation of teaching, strengthen service and supporting function in the applied teaching and establish the applied teaching implementation platform. Under the guidance of these target incentive systems, the teachers transform toward the applied teaching method, reform the teaching content, change the teaching methods and teaching roles, look for ways to stimulate the students' intrinsic learning motivation, explore effective evaluation methods and systems, seek skills 
to enhance the students' application ability, establish an effective applied teaching system, thus ultimately contributing to achieve the goal of the applied talents training.

\section{EMPIRICAL ANALYSIS}

In the teaching practice, the effective use of target incentive in three private schools in Xi'an indicates that, the target incentive has a tremendous impact on the applied talents training. Since 2010, three private schools in Xi'an have begun to implement the pilot reform of the target incentive and process evaluation, and fully mobilized the teachers' enthusiasm and creativity in the applied teaching through the establishment of target incentive system of the applied talents training. Furthermore, these three schools have given full play to the characteristics of different professional courses for some professional courses adopting the flexible teaching methods, and also adopted characteristic teaching methods. Through the process evaluation, it also greatly improves the students' learning motivation and enthusiasm. By the end of 2015, there are 68 professional courses with successful reform.

The survey of the implementation effect of the target incentive system and process evaluation system in three private schools reveals that, 86 teachers conducting reform generally believe that, the target incentive system makes them devote themselves to the applied teaching under the pressure, and the teaching is very effective so that they have a great "sense of accomplishment". Meanwhile, the random sample survey for the students who participate in the course learning reveals that, $98 \%$ of students believe that, the applied teaching method and process evaluation reform plays roles in greatly promoting their own ability; $56 \%$ of students believe that, such a reform makes them have a greater pressure; $89 \%$ of students believe that, such a reform greatly suppresses their learning sluggishness; $77 \% \%$ of students believe that, their comprehensive ability is improved through learning these reformed courses. In addition, the survey of these students' internship enterprises reveals that, the students who participate in the course learning are ge- nerally able to directly adept to the post in the relevant fields without too much training. These surveys reveal that, the target incentive and process evaluation systems and measures of three private schools reach the goal of applied talents training.

\section{CONCLUSION}

Through analysis of the teaching and learning behavior of the college teachers and students by the use of the game analysis method in the applied talents training process, this paper finds that, there is an incentive paradox between the traditional teaching evaluation methods and applied talents training goal. Therefore, this paper builds the closed-loop constraint system of target incentive of the applied talents training goal to solve the incentive paradox, and puts forward measures target incentive and methods of implementation from three levels: teaching affairs department, teachers and students

\section{ACKNOWLEDGEMENT}

This paper is financially supported by the Excellent Course Construction of International Settlement and the Demonstration and Featured Speciality Construction of International Trade.

\section{REFERENCES}

[1] Chu Lingli \& Wu Hansheng. 2009. Research of economic management personnel training mode in private colleges. Economic Research Guide, (1).

[2] Zhang Jie. 2008. Paradox of employment difficulty talent supply and demand. Zhongshan University Press. 3

[3] Peng Lei. 2011. Current employment status and countermeasure analysis of private colleges. Journal of Harbin Institute. (3): 142-144.

[4] Chu Lingli. 2013. Research of evaluation system of economic management personnel training mode in private colleges. China Power Education, (9).

[5] Chu Lingli, \& Liu Junxia. 2014. Process incentives and applied talents training. Economic Research Guide, (11). 